\title{
E-INFORMATION SYSTEM DESIGN OF STUDENT ADMISSION IN AMERICAN INDONESIAN EDUCATIONAL INSTITUTION CIJANTUNG BRANCH
}

\author{
Anggi Oktaviani ${ }^{*}$ ), Dahlia Sarkawi ${ }^{2}$, Deny Novianti ${ }^{3}$, Achmad Chaerul Amri ${ }^{4}$ \\ Teknik Informatika \\ Universitas Nusa Mandiri \\ anggi.aov@nusamandiri.ac.id $\left.{ }^{1 *}\right)$ \\ Administrasi Perkantoran / Sistem Informasi \\ Universitas Bina Sarana Informatika \\ dahlia.dls@bsi.ac.id², denynov.dov@bsi.ac.id³, achmadchaerul29@gmail.com ${ }^{4}$
}

(*) Corresponding Author

\begin{abstract}
Abstrak
Saat ini perusahaan, organisasi dan institusi sangat membutuhkan perkembangan teknologi dan sistem informasi khususnya teknologi informasi melalui media internet.. Lembaga Pendidikan Indonesia Amerika Cabang Cijantung yang sampai saat ini masih belum terkomputerisasi. Saat ini, proses registrasi menjadi peserta didik di Lembaga Pendidikan Indonesia Amerika Cabang Cijantung tergolong masih manual baik dari pengisian formulir yang disediakan oleh Lembaga Pendidikan Indonesia Amerika Cabang Cijantung sampai menjadi peserta didik. Biasanya proses pendataan sedikit terhambat dikarenakan jumlah pendaftar lebih banyak dibandingkan customer service dan terkadang customer service kesulitan dalam membaca formulir calon peserta didik. Hal ini menyebabkan pelayanan dari customer service Lembaga Pendidikan Indonesia Amerika Cabang Cijantung tidak optimal. Penelitian ini menggunakan menggunakan model waterfall sebagai model pengembangan perangkat lunak. Dari penelitian yang dilakukan diharapkan dapat menghasilkan sebuah sistem pengendalian sistem penerimaan peserta didik baru yang dapat membantu customer service dalam pendataan calon peserta didik dan mengelola formulir calon peserta didik. Perancangan sistem penerimaan peserta didik baru diharapkan menjadi lebih efektif dan efisien. Sehingga baik saat proses pendaftaran dapat diselesaikan dalam waktu yang tidak lama. Sistem ini juga diharapkan bisa meminimalisir kesalahan pendataan yang dilakukan oleh customer service.
\end{abstract}

Kata kunci: Perancangan Sistem Informasi, Sistem Penerimaan Peserta Didik, Waterfall

\begin{abstract}
Currently, companies, organizations and institutions are in dire need of the development of technology and information systems, especially information technology through the internet. The American Indonesian Education Institute, the Cijantung Branch, which until now has not yet been computerized. Currently, the registration process to become a student at the American Indonesian Education Institute Cijantung Branch is still manual, both from filling out forms provided by the American Indonesian Education Institute Cijantung Branch to becoming a student. Usually the data collection process is a bit hampered because the number of applicants is more than customer service and it is too difficult for customer service to read prospective student forms. This causes the service from the customer service of the American Indonesian Education Institute Cijantung Branch is not optimal. This study uses the waterfall model as a software development model. From the research conducted, it is expected to produce a new student acceptance control system that can assist customer service in collecting data on prospective students and managing prospective student forms. The design of the new student admission system is expected to be more effective and efficient. So it's good when registration can be completed in a short time. This system is also expected to minimize data collection errors made by customer service.
\end{abstract}

Keywords: Information System Design, Student Admission System, Waterfall 


\section{INTRODUCTION}

Technological developments from time to time are increasingly rapid, marked by the number of existing innovations such as smart devices that can be carried anywhere by hand (Sidik \& Rahmawati, 2018). Therefore, the development of technology that has accelerated we must make good use to be used in facilitating human work in any field.

The internet is a medium that can bring negative and positive changes, it depends on how we take benefits to support work patterns so that they can produce better changes (Ramdhan \& Wahyudi, 2019). One of the positive changes of the internet is that it makes it easier for people to know things in real-time and also quickly. We must make good use of the internet today, not to be misused for things that are not important.

This convenience and sophistication are often used in everyday life (Purnia et al., 2019), one of which is in the world of education which is one of the aspects that most take advantage of technological advances. Admission of new students is one of the processes that exist in the educational environment that is used to screen suitable new students who will later become students (Jimmie et al., 2018). The process of accepting new students using the sophistication of the internet provides convenience for parents, and also students when going to apply to the intended school. Since everything is already online, there is no need to come to school and queue to register new students (Ismi et al., 2020).

So that this creates competitive competition between every educational institution, including private educational institutions (Witanto \& Solihin, 2016). There are many ways to get an education, ranging from formal and non-formal education. Informal education, learners must follow the selection of new student admissions held by the school to be able to study at the school (Sarwosri et al., 2020). There are many ways to take education, ranging from formal and non-formal education. Informal education, students must take part in the selection of new student admissions held by the school to be able to study at the school (Sarwosri et al., 2020). There is also non-formal education that comes as a complement to formal education such as courses or training institutions.

The purpose of implementing PSB online is to create transparency in new student admissions and ease the selection of new students. In terms of processing data and information, these schools have indeed used a computerized system, but this is only limited to certain parts, such as typing reports related to schools or making education letters only
(Astuti et al., 2014). One of the conveniences felt from the acceptance of new students online is that students and parents no longer need to come to school and queue while carrying some files to register their children. Because with the acceptance of students online, parents and students can register from home or from anywhere as long as there is internet access.

This manual process of admitting new students is considered less effective and efficient, both for the new student admissions committee and for prospective new students themselves. This is because the process of implementing the acceptance of new students can take time and energy (Alaih et al., 2020). The acceptance of new students manually will certainly be more draining time and energy, because the number of students who will apply and also with the deadline given by the government makes the school overwhelmed when the process of accepting new students.

Gap analysis (GAP or Gender Analysis Pathway) is a comparison of actual performance with potential or expected performance. This method is a business evaluation tool that focuses on the gap in the current performance of government agencies with previously targeted performance, for example, those already listed in the business plan or annual plan for each function of the government agency. The gap analysis also identifies what actions are needed to reduce the gap or achieve the expected performance in the future (Nugraha \& Yuniawan, 2017). By using this method as an evaluation tool of the program that has been created, it is expected that it can hereby find out whether the program is appropriate or not with the expected target.

The American Indonesian Education Institute, the Cijantung Branch, was established several years ago, which is located on Jalan Haji Hasan Baru, Pasar Rebo, East Jakarta. Currently, the registration process to become a student at the Cijantung Branch of the American Indonesian Education Institute is still manual, both from filling out the forms provided by the American Indonesian Education Institute, the Cijantung Branch, to becoming a student.

The problem that occurs is that the new student admissions process (PSB) is still using the conventional system, so that prospective students sometimes have difficulty getting information to carry out the registration process (Rosmiati, 2020). This causes the customer service of the American Indonesian Education Institute Cijantung Branch to be not optimal. Likewise, the process of making new student admission selection reports takes longer (Arum Ningtyas et al., 2018). Another problem that often arises is the existence of a long document 
administration process, less integrated or even lost. This is because of the number of documents that must be handled during the admission of new students, then the loss of documents can occur.

From the problems faced, the American Indonesian Education Institute Cijantung Branch requires an information system that has been computerized, because it is very useful, especially in the acceptance of prospective new students. Acceptance of new prospective students using a computerized system can help students, including the American Indonesian Education Institute, Cijantung Branch because data and information for prospective new students can be accessed anywhere via the internet so that it can save time and energy. The process of accepting new students is expected to be more effective and efficient. This system is also expected to minimize data collection errors made by customer service.

\section{RESEARCH METHODS} study are:

The data collection methods used in this

1. Observation Method

In this study, the authors observed and recorded directly regarding the activities of new student admissions carried out at the American Indonesian Education Institute.

2. Interview

The author carried out data collection techniques by holding direct questions and answers which were carried out face-to-face with Mrs. Santi Mayasari, S.Sos as Branch Manager at the American Indonesian Education Institute regarding the acceptance of new students.

3. literature review

The author collects data from books, journals, and articles on the internet which are intended to obtain materials that are theoretical in nature and serve as the basis for thinking and comparison with practical matters in writing this research obtained from several sources including through the library and the internet.

\section{Types of research}

This research uses a qualitative method and case study approach. The main techniques in collecting data are observation and in-depth interviews. The results obtained show that verbal communication used by family members who have not studied indigo more deeply prefer one-way communication and verbal communication is commanding (Arkandito et al., 2019). Another reason to use qualitative methods is that they can generally be used in research on people's lives and also they can understand the hidden from a phenomenon that is sometimes difficult to understand.

\section{Time and Place of Research}

This research was conducted at the American Indonesian Education Institute, the Cijantung Branch, which was established several years ago, which is located on Jalan Haji Hasan Baru, Pasar Rebo, East Jakarta.

\section{Research Target / Subject}

The purpose of this study is to design a new student admission system at the American Indonesian Education Institute, Cijantung Branch as a solution to the problem of less than optimal student registration.

\section{Procedure}

The method used in this research is Waterfall. SDLC model waterfall (waterfall) is often also called a linear sequential model (linear sequential) or classical life cycle (classic life cycle) (Sidik \& Rahmawati, 2018). SDLC model waterfall (waterfall) is often also called a linear sequential model (linear sequential) or classical life cycle (classic life cycle) (Tabrani Muhamad, 2017). With the waterfall model, we use a software approach in sequence starting from the analysis, design, coding, testing, and also the supporting stage.

\section{Data, Instruments, and Data Collection Techniques}

$M$ The method used in this research is Waterfall. SDLC model waterfall (waterfall) is often also called a linear sequential model (linear sequential) or classical life cycle (classic life cycle) (Frieyadie, 2016; Sidik \& Rahmawati, 2018). With the waterfall model, we use a software approach in sequence starting from the analysis, design, coding, testing, and also the supporting stage. The following is an explanation of this model:

\section{Software Requirements Analysis}

The method involved with social occasion prerequisites is done seriously to indicate programming necessities so clients can get what sort of programming is required by the client. Programming necessities particulars at this stage should be recorded.

\section{Design}

Programming configuration is a multi-step process that spotlights the plan of a product program including information structures, programming design, interface portrayal, and coding methodology. This stage translates software requirements from the requirements analysis stage 
to the design representation so that they can be carried out into a program at a later stage. The product configuration created at this stage likewise should be recorded.

\section{Program Code Generation}

The plan should be converted into a product program. The aftereffect of this stage is a PC program by the plans that have been made at the planning stage.

4. Testing

Testing centers around the product as far as the hotel and practical and guarantees that all parts are tried. This is done to limit mistakes (blunders) and guarantee the subsequent result is ideal.

5. Support or Maintenance

Try not to preclude the chance of programming changes when it has been shipped off the client. Changes can happen because mistakes that show up and are not recognized during testing of the product need to adjust to the new climate. The help or upkeep stage might rehash the advancement interaction going from particular examination to changes to existing programming, however not to make new programming.

\section{RESULTS AND DISCUSSION}

The following is an explanation of the stages of the waterfall method, namely:

1. Software Requirements Analysis

a. New Students Page

1) New students can access the website of the American Indonesian Education Institute Cijantung Branch including home, latest information, about us, gallery, contact.

2) New students access the login and register menu, log in for those who already have an account, and register for those who do not have an account to register for new students.

3) New students can enter the new student registration form.

4) New students can upload proof of payment.

b. Customer Service Page

1) Customer Service can log in.

2) Customer Service can manage new student registration data.

3) Customer Service can manage proof of payment.

c. Branch Manager Page

1) The branch Manager can view reports.

2. Design

In this stage there are three stages of design, namely use case diagrams, activity diagrams, and class diagrams. a. System Model Design

1. Use Case Diagram Proposed

Here's an overview of the use case that has been created.

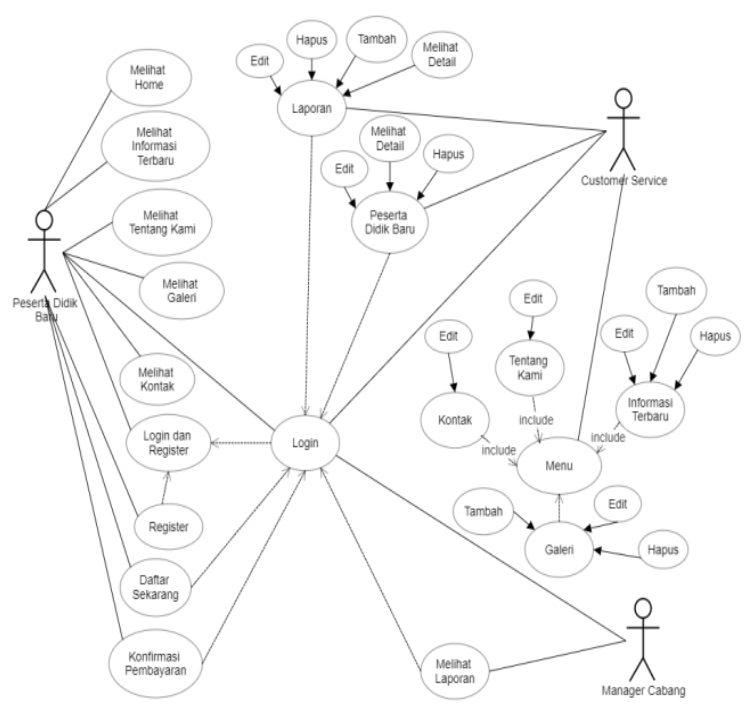

Figure 1. Use Case Diagram

Figure 1 describes the use case diagram which is the main component in a system. Use case diagrams to explain the relationship between actors and the system created.

\section{Activity Diagram}

Here's an overview of the activity diagram that has been created.

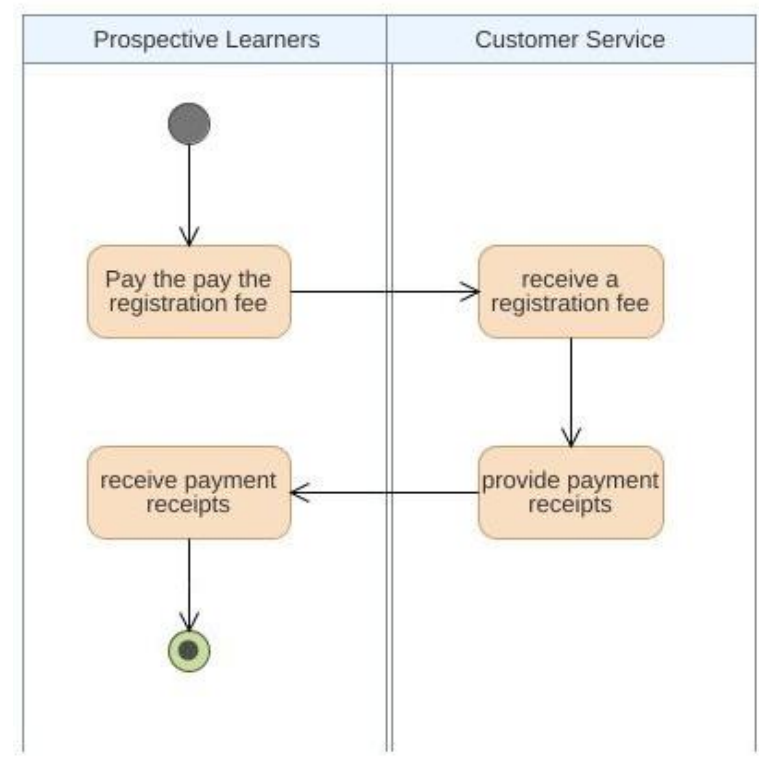

Figure 2. Activity Procedure Payment 
Figure 2 describes the payment procedure activity in the system. The function of the activity diagram is to describe what processes occur in the system.

\section{Class Diagram}

The following is a description of the class diagram of the E-Information System that has been created.

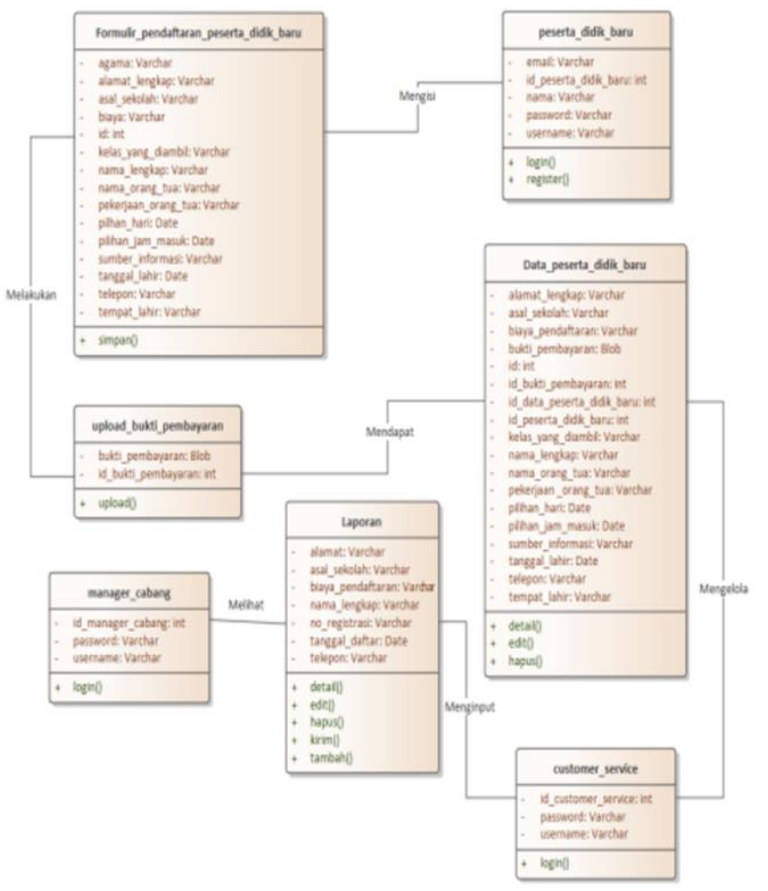

Figure 3. Class Diagram

Figure 3 describes the class diagram in the system. The function of the class diagram is to describe various models with various components and what must exist in a system.

b. Interface Design

1. Interface Home

Here's a view of the home page that has been created.

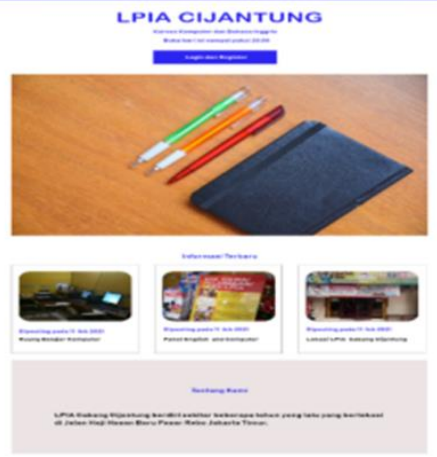

Figure 4. Interface Home
Figure 4 describes the home interface. Where this is the page for new students when opening the web of the American Indonesian Education Institute.

2. Interface Customer Service Login Page

The following is the display of the Customer Service Login Page that has been created.

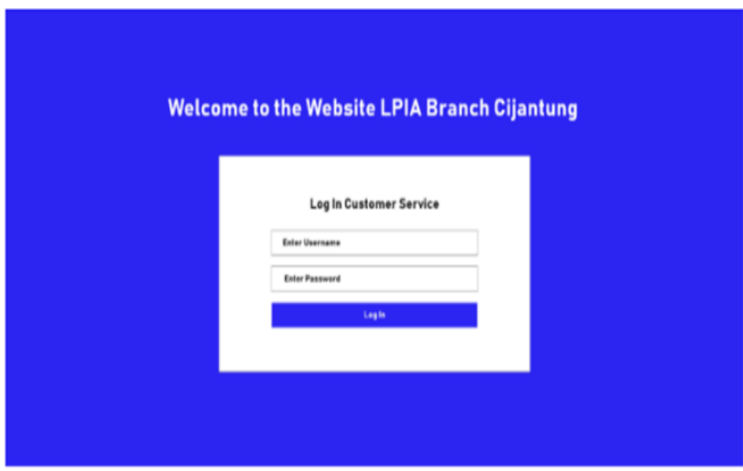

Figure 5. Interface Customer Service Login

Figure 5 describes the login page interface which is a page for customer service to enter the system.

3. Interface New Student Data Page

The following is the view of the New Student Data Page that has been created.

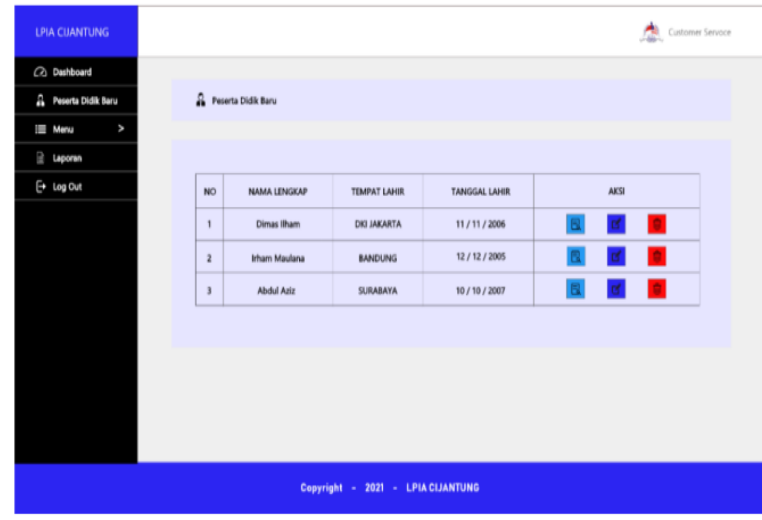

Figure 6. Interface New Student Data Page

Figure 6 describes the interface for the new student data page. Where on this page customer service can process new student data.

4. Interface Branch Manager Login Page

The following is the view of the Branch Manager Login page that has been created. 


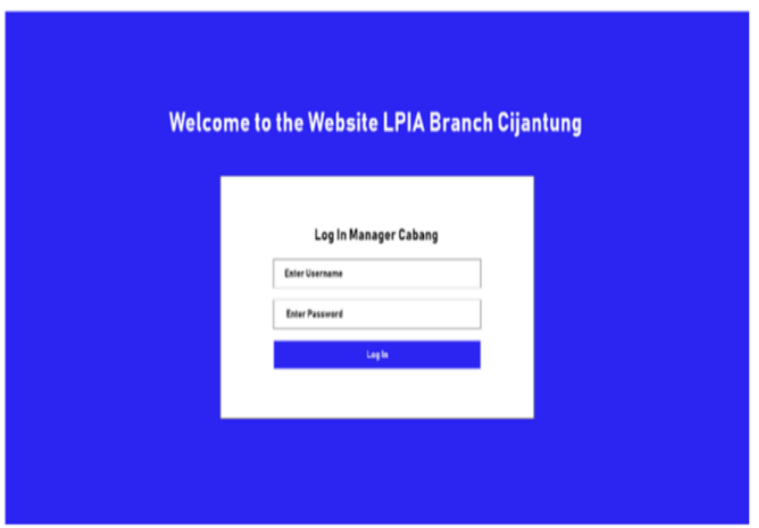

Figure 7. Interface Branch Manager Login

Figure 7 depicts the branch manager login page. Where on this page only branch managers can only access it.

\section{Interface Report Page}

The following is a view of the Report Page that has been created.

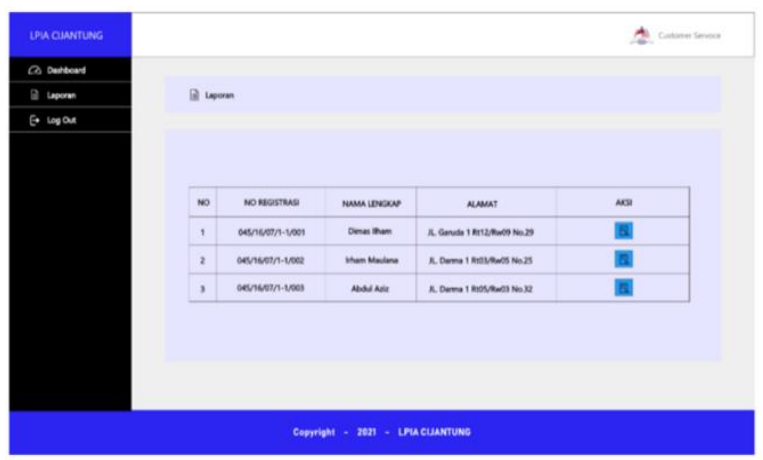

Figure 8. Interface Report Page

Figure 8 describes the report page. Here is displayed a report that has been made by customer service.

\section{Program Code Generation}

The web for new student admissions at the American Indonesian Education Institute was designed and built using programming languages, HTML, CSS, and sublime applications. Where this stage is done by transferring the results of the system design into a predetermined programming language. The following is a little program code that has been made in this research:

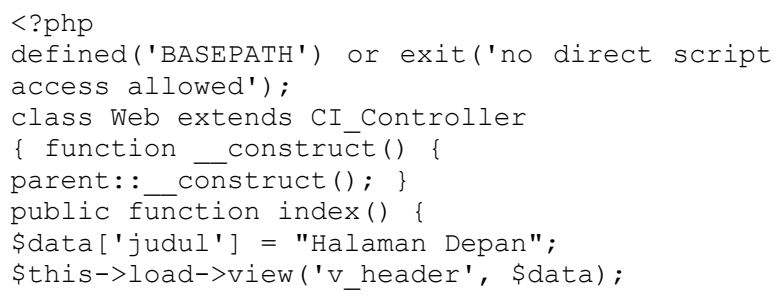

\$this->load->view('v_index', \$data)

\$this->load->view('v_footer', \$data);

\}

public function about()

\$data['judul'] = "Halaman About";

\$this->load->view('v header', \$data);

\$this->load->view('v_about', \$data);

\$this->load->view('v_footer', \$data);

\}

4. Testing

At this stage, the author conducts testing of the system that has been created. Testing is done by evaluating the system that has been made whether it can run well and as expected. If there are still errors and omissions, they can be corrected immediately. According to Pangistu et al in research (Novianti et al., 2021). UAT is a trying cycle by respondents which is expected to deliver reports that are utilized as proof that the framework being created is $\mathrm{OK}$ or not by the respondent, assuming the outcomes are considered to address the issues of the respondent, then, at that point, the application can be applied.

Testing utilizing UAT centers around the course of program info and result. The test was conducted by asking several questions to 15 respondents. Then the test results from the respondents were assessed based on 5 categories, namely, A (Very Good), B (good), C (fair), D (Not Good), and E (Very Bad).

The following are the results of the tests that have been carried out which can be seen in table 1 .

Table 1. Test UAT

\begin{tabular}{|c|c|c|c|c|c|c|}
\hline \multirow[t]{2}{*}{ NO } & \multirow[t]{2}{*}{ Pertanyaan } & \multicolumn{5}{|c|}{ Jawaban } \\
\hline & & A & B & $\mathrm{C}$ & D & $\mathbf{E}$ \\
\hline 1 & $\begin{array}{l}\text { Is the web view of } \\
\text { admissions of these new } \\
\text { students } \\
\text { interesting? }\end{array}$ & 10 & 3 & 2 & 0 & 0 \\
\hline 2 & $\begin{array}{l}\text { Is the menu on the new } \\
\text { student admissions web } \\
\text { understandable? }\end{array}$ & 9 & 5 & 1 & 0 & 0 \\
\hline 3 & $\begin{array}{l}\text { Can the menu on the new } \\
\text { student admissions web } \\
\text { make the admissions } \\
\text { process easier? }\end{array}$ & 9 & 4 & 2 & 0 & 0 \\
\hline 4 & $\begin{array}{l}\text { Is the new admissions web } \\
\text { easy to use? }\end{array}$ & 10 & 4 & 1 & 0 & 0 \\
\hline 5 & $\begin{array}{l}\text { Is the data from the new } \\
\text { student admissions web } \\
\text { easy to create a report? }\end{array}$ & 9 & 3 & 3 & 0 & 0 \\
\hline & Total & 47 & 19 & 9 & 0 & 0 \\
\hline
\end{tabular}

The results of the recapitulation of answers from all respondents can be seen in Table 1 . The majority of respondents gave positive responses about the web created, this can be seen from the number of very good answers with a value of 47 , while respondents who think quite well are 9. Therefore it can be concluded that the web that has been created is well received by users. 


\section{CONCLUSIONS AND SUGGESTIONS}

\section{Conclusion}

So far, data management at the American Indonesian Education Institute, Cijantung Branch is still using a manual system so that it is still ineffective and inefficient. It is hoped that creating a web design for the New Student Admissions system, can be problem solving and facilitate the registration process and acceptance of new students at the American Indonesian Education Institute.

\section{Suggestion}

In a web, periodic maintenance is needed to reduce errors in the system. It is also expected to always update the data on the web so that the data available on the web is the latest data according to the conditions at the American Indonesian Education Institute.

\section{REFERENCES}

Alaih, R. I., Rahadian, D., \& Imania, K. A. N. (2020). Pengembangan Sistem Informasi Penerimaan Peserta Didik Baru Baru Berbasis Web Di Smk Al-Halim Garut. Jurnal Petik, 6(2), 57-70. https://doi.org/10.31980/jpetik.v6i2.860

Arkandito, G. F., Maryani, E., Rahmawan, D., \& Wirakusumah, T. K. (2019). Komunikasi Verbal Pada Anggota Keluarga Yang Memiliki Anak Indigo. Jurnal Manajemen Komunikasi, 1(1), 42-56. https://doi.org/10.24198/jmk.v1i1.9955

Arum Ningtyas, D., Badrul, M., \& Nur Sulistyowati, D. (2018). Sistem Informasi Penerimaan Peserta Didik Baru Pada SMP Ar-Ridha Jakarta. Jurnal TECHNO Nusa Mandiri, 15(1), 19-24. https://doi.org/10.33480/techno.v15i1.53

Astuti, I. F., Marisa, D., \& Febriani, A. (2014). Menengah Pertama Berbasis Web ( Studi Kasus Kabupaten Kutai Kartanegara ). Informatika Mulawarman, 9(2), 35-40.

Frieyadie, F. (2016). Penerapan Model Watefall Pada Rancang Bangun Sistem Informasi Penjualan Online Hid Bullaes. JITK (Jurnal Ilmu Pengetahuan Dan Teknologi Komputer), 2(1), 1-4. https://doi.org/10.33480/JITK.V2I1.226

Ismi, I., Willis, R., Soliah, S., Tiawati, I., \& Yulianti, Y. (2020). Perancangan Sistem Informasi Pendaftaran Siswa Baru di SMK YASTRIF 1 Parung Panjang Berbasis Web. Jurnal Teknologi Sistem Informasi Dan Aplikasi, 3(4), 231-236.

https://doi.org/10.32493/JTSI.V3I4.7177

Jimmie, Ma'ruf, M. I., \& Mahendra, D. (2018). Sistem
Informasi Penerimaan Siswa Baru Berbasis Web Di Sekolah Menengah Pertama Negeri 43 Palembang. Jurnal Digital Teknologi Informasi, 1(2), 98-105. https://jurnal.umpalembang.ac.id/digital/article/view/2370

Nugraha, N. C., \& Yuniawan, A. (2017). Implementasi Importance and Performance Analysis (IPA) Dalam Pelaksanaan Penilaian Kinerja Karyawan (PNS) (Studi Pada Kementerian Pekerjaan Umum Dan Perumahan Rakyat, SNVT PJPA Pemali-Juana PPK PAT Dan PPK PAB). Diponegoro Journal of ..., 6(4), 1-14. https://ejournal3.undip.ac.id/index.php/djo $\mathrm{m} /$ article/view/18020

Purnia, D. S., Rifai, A., \& Rahmatullah, S. (2019). Penerapan Metode Waterfall dalam Perancangan Sistem Informasi Aplikasi Bantuan Sosial Berbasis Android. Seminar Nasional Sains Dan Teknologi 2019, 1-7. https://jurnal.umj.ac.id/index.php/semnaste k/article/view/5238

Ramdhan, N. A., \& Wahyudi, D. (2019). Sistem Informasi Penerimaan Peserta Didik Baru (PPDB) Berbasis WEB Di SMP Negri 1 Wanasari Brebes. Jurnal Ilmiah Intech: Information Technology Journal of UMUS, 1(01), 56-65. https://doi.org/10.46772/intech.v1i01.38

Rosmiati, M. (2020). Sistem Informasi Penerimaan Peserta Didik Baru Berbasis Web. Indonesian Journal on Software Engineering (IJSE), 6(2), 182-194.

https://doi.org/10.31294/ijse.v6i2.9003

Sarwosri, S., Amalia, I. Z., Hariadi, V., \& Suadi, W. (2020). Sistem Informasi Penerimaan Peserta Didik Baru Provinsi Jawa Timur bagian Kantor (back end). Sewagati, 4(3), 154. https://doi.org/10.12962/j26139960.v4i3.7 679

Sidik, F., \& Rahmawati, M. (2018). Perancangan Sistem Informasi Pendaftaran Siswa Baru Berbasis Web Pada SMK Bina Putra Jakarta. Paradigma-Jurnal Komputer Dan Informatika, 20(1), 119-128. https://ejournal.bsi.ac.id/ejurnal/index.php/ paradigma/article/view/3051

Tabrani Muhamad, E. P. (2017). Penerapan Metode Waterfall Pada Sistem Informasi Inventori PT. Pangan Sehat Sejahtera. Jurnal Inkofar, 1(2), 30-40.

http://politeknikmeta.ac.id/meta/ojs/index. php/inkofar/article/view/12

Witanto, R., \& Solihin, H. H. (2016). Perancangan Sistem Informasi Penerimaan Siswa Baru Berbasis Web (Studi Kasus: SMP Plus Babussalam Bandung). Jurnal Infotronik, 2(1), 54-63. 
http://183.91.79.105/index.php/infotronik/ article/view/9 